\title{
Antagonisme beberapa bakteri endofit Arecaceae terhadap Curvularia sp. patogen penyebab bercak daun yang diisolasi dari tanaman kelapa kopyor
}

\author{
Antagonism of selected Arecaceae endophytic bacteria against Curvularia sp. leaf spot pathogen isolated \\ from coconut kopyor \\ Deden Dewantara ERIS ${ }^{\left.1)^{*}\right)}$, Abdul MUNIF²), Bonny PW SOEKARNO ${ }^{2)} \&$ Agus PURWANTARA ${ }^{3)}$ \\ ${ }^{1)}$ Pusat Penelitian Bioteknologi dan Bioindustri Indonesia, Jl Taman kencana No 1 Bogor 16128, Indonesia \\ ${ }^{2)}$ Departemen Proteksi Tanaman, Institut Pertanian Bogor, Jl Kamper, Kampus Darmaga, Bogor 16680 \\ 3) PT Mars Symbioscience Indonesia, Jl. Kima 10 Kav. A6, Kawasan Industri Makassar, Sulawesi Selatan 90241
}

Diterima tgl 7 Mei 2018/ disetujui tgl 13 September 2018

\begin{abstract}
Coconut kopyor is one of the most important commodities. One of the problems in coconut kopyor cultivation is grey leaf spot disease caused by Curvularia sp. Using endophytic bacteria is one of the control technique that is environmentally friendly. A total of 40 selected endophytic Arecaceae bacteria isolated from coconut kopyor, palm oil, aren, nibung and pejibaye were tested for their inhibitory ability to Curvularia sp. through antibiotic and volatile organic compound (VOC) test. The antibiotic test showed that thirty three endophytic bacteria isolates have inhibitory capacity against Curvularia $s p$. in a range of inhibition from $4.4 \%$ to $86.6 \%$. Isolates with the highest inhibition were EAKSS 502, EAKSS 520 and EAKSS 507. VOC test showed that EAPJN 216, EAKSS 532, EAAPN 225, EAAPN 506, $E A A P N 507$ and EAAPN 557 were produced VOC that suppressed the growth of Curvularia sp fungal colonies in a range from $92.27 \%$ to $97.21 \%$. Based on the best combination of antibiotic and production of volatile organic compound test, there were four potential isolates to inhibit the growth of Curvularia $s p$. in vitro i.e. EAKSS 502, EAKSS 507, EAKPN 201 and EAPJN 216. Those isolates were molecularly identified as Serratia marcescens strain PIGB81, Burkholderia sp. DOP Ma316, S. marcescens strain RY21 and $\mathrm{S}$. marcescens strain LB21. The four isolates were isolated from different plants such oil palm, coconut kopyor and pejibaye.
\end{abstract}

[Keywords: antibiotics, Burkholderia, malformation, Serratia, suppression, volatile compound]

*) Penulis korespondensi: dewantara40@gmail.com

\begin{abstract}
Abstrak
Kelapa kopyor saat ini menjadi salah satu komoditas perkebunan yang penting. Salah satu masalah dalam pembudidayaan kelapa kopyor adalah serangan penyakit bercak kelabu yang disebabkan oleh cendawan Curvularia sp. Penggunaan bakteri endofit merupakan salah satu cara control yang ramah lingkungan. Sebanyak 40 isolat bakteri endofit asal tanaman Arecaceae diisolasi dari tanaman kelapa kopyor, kelapa sawit, aren, nibung dan pejibaye diujikan kemampuan penghambatannya terhadap Curvularia sp. melalui uji antibiosis dan uji produksi senyawa organik volatil (VOC). Uji antibiosis menunjukkan sebanyak 33 isolat bakteri endofit menunjukkan daya penghambatan terhadap cendawan Curvularia sp. dengan kisaran 4,4\%-86,6\%. Penghambatan terbesar yakni isolat EAKSS 502, EAKSS 520 dan isolat EAKSS 507. Pengujian produksi senyawa organik volatil menunjukkan EAPJN 216, EAKSS 532, EAAPN 225, EAAPN 506, EAAPN 507 dan EAAPN 557 menghasilkan komponen volatil organik yang menekan pertumbuhan koloni cendawan Curvularia sp. pada kisaran 92,27\%97,21\%. Berdasarkan kombinasi data pengujian antibioisis dan produksi senyawa organik volatil terdapat 4 isolat bakteri endofit yang berpotensi menghambat perkembangan Curvularia sp. yaitu isolat EAKSS 502, EAKSS 507, EAKPN 201 dan EAPJN 216. Hasil identifikasi secara molekuler ke empat isolat tersebut berturut-turut adalah Serratia marcescens strain PIGB81, Burkholderia sp. DOP Ma316, $S$. marcescens strain RY21 dan $S$. marcescens strain LB21. Keempat isolat tersebut diisolasi dari tanaman yang berbeda yakni kelapa sawit, kelapa kopyor dan pejibaye.
\end{abstract}


[Kata kunci: antibiotik, Burkholderia, malformasi, penghambatan, Serratia, komponen volatil].

\section{Pendahuluan}

Kelapa kopyor (Cocos nucifera L var. kopyor) saat ini semakin dikenal dan diminati oleh masyarakat. Buah kelapa kopyor memiliki rasa yang lezat dengan endosperm (daging buah) yang sebagian besar terlepas disertai volume air kelapa yang lebih sedikit dibandingkan dengan kelapa normal. Keistimewaan kopyor dan harga yang bisa mencapai 5-6 kali harga kelapa normal menyebabkan usaha budidaya kelapa kopyor semakin menarik, diminati banyak orang mulai dari petani, Dinas Perkebunan, pengusaha serta pelaku bisnis lainnya.

Pembudidayaan kelapa kopyor bukan tanpa masalah. Salah satu penyakit tanaman yang menyerang tanaman kelapa kopyor di pembibitan dan tanaman muda diantaranya penyakit bercak daun kelabu yang disebabkan oleh Curvularia sp. Kittimorakul et al., (2013) menyatakan bahwa tingkat keparahan penyakit bercak daun dapat terjadi hingga 61\%. Serangan Curvularia sp. mengakibatkan kerusakan jaringan yang menyebabkan tanaman tidak dapat tumbuh secara optimal bahkan menuju kematian.

Salah satu teknik penanggulangan penyakit tanaman adalah dengan memanfaatkan bakteri endofit. Bakteri endofit merupakan bakteri yang dapat hidup, berkembang dengan baik, berasosiasi di dalam jaringan tanaman tanpa menimbulkan gejala penyakit pada tanaman tersebut (Hallmann, 2001). Bakteri endofit bersimbiosis dengan tanaman, memperoleh nutrisi yang berasal dari hasil metabolisme tanaman. Bakteri endofit selain memperoleh nutrisi dari tanaman juga memproteksi tanaman dari patogen selama hidupnya (Tanaka et al., 1999; Adeline et al., 2008).

Pemanfaatan bakteri endofit dalam pengendalian penyakit diantaranya adalah bakteri Pseudomonas aeruginosa sebagai Plant Growth Promoting Rhizobacteria (PGPR) dan agens pengendali Ganoderma pada bibit tanaman kelapa sawit (Sapak et al., 2008). Pada kopi dan tanaman lada aplikasi bakteri endofit perakaran mampu menekan perkembangan penyakit yang disebabkan oleh serangan nematoda (Munif \& Giyanto, 2015; Harni \& Munif, 2012). Pada kelapa kopyor Eris et al., (2017) melaporkan potensi bakteri endofit dalam mengendalikan patogen Pestalotiopsis sp. penyebab penyakit bercak daun. Penelitian ini bertujuan untuk mengidentifikasi isolat bakteri endofit asal tanaman Arecaceae terseleksi yang memiliki kemampuan penghambatan terhadap cendawan Curvularia sp. penyebab bercak daun kelabu pada kelapa kopyor.

\section{Bahan dan Metode}

Isolasi bakteri endofit dan cendawan patogen bercak Curvularia $s p$.

Sampel akar dan daun tanaman pejibaye (Bactris gasipaes), kelapa kopyor (Cocos nucifera), kelapa sawit (Elaeis guinensis), aren (Arenga pinnata) dan nibung (Oncosperma filamentosa) diperoleh dari wilayah dataran rendah Bogor yakni kawasan Dramaga dan Ciampea. Sampel tersebut dibawa ke laboratorium dan dipotong berukuran $3-4 \quad \mathrm{~cm}^{2}$. Selanjutnya dilakukan ekstraksi untuk memperoleh isolat bakteri endofit (Rajendran et al., 2012; Munif et al., 2012).

Untuk mengisolasi cendawan Curvularia sp., jaringan daun kelapa kopyor bergejala bercak kelabu dipotong-potong hingga berukuran 2-4 $\mathrm{cm}^{2}$. Potongan daun disterilisasi permukaan dengan perendaman pada $\mathrm{NaOCl} 2 \%$ selama 3 menit, alkohol $70 \%$ selama 2 menit dan diakhiri dengan bilasan air steril sebanyak 3 kali. Jaringan daun kemudian ditanam pada cawan Petri berisi media PDA dan diinkubasi selama 7 hari pada suhu ruangan. Pertumbuhan cendawan diamati setiap hari, dimurnikan dan secara berkala diremajakan pada media PDA dalam cawan Petri dan tabung reaksi.

\section{Uji antibiosis}

Uji antibiosis bakteri endofit dilakukan menggunakan media PDA pada suhu ruang selama 7 hari mengacu pada Munif et al., (2012). Pada akhir masa inkubasi (hari ke-7 pengamatan), daya penghambatan dihitung dengan formula ((R1R2)/R1) x 100\%; dimana R1 adalah jari-jari koloni cendawan patogen yang menjauhi koloni bakteri endofit dan R2 adalah jari-jari koloni cendawan patogen yang mendekati koloni bakteri endofit (Munif et al., 2012; Eris et al., 2017).

Uji produksi senyawa organik volatil (volatile organic compound/VOC) terhadap perkembangan cendawan Curvularia sp.

Pengujian ini, dilakukan dengan menggunakan 2 buah cawan Petri berukuran sama yang dilekatkan saling telungkup. Cawan bagian atas berisi media Nutrient Agar (NA) dengan kultur bakteri endofit berusia 2 hari. Cawan bagian bawah berisi media PDA dengan kultur cendawan patogen Curvularia sp berusia 7 hari berbentuk lingkaran dengan diameter $10 \mathrm{~mm}$. Kultur cendawan Curvularia sp. dilekatkan berhadapan dengan kultur bakteri menggunakan sealer atau selotip (sehingga kondisi kedap udara) dan diinkubasikan selama 7 hari pada suhu ruang. Pengama- 
tan dilakukan pada hari ke-7 dengan cara mengukur diameter koloni cendawan (Yuan et al.,2012). Sebanyak 4 isolat bakteri endofit dengan persentase hambatan di atas 50\% berdasarkan pengujian antibiosis sebagai pertimbangan utama dan uji senyawa organik volatil dipilih untuk selanjutnya diidentifikasi secara molekuler.

\section{Identifikasi bakteri endofit secara molekuler Isolasi DNA bakteri endofit}

Empat isolat bakteri endofit terpilih berdasarkan kombinasi data uji antibiosis dan uji produksi senyawa organik volatil. Isolat tersebut antara lain EAKSS 502, EAKSS 507, EAKPN 201 dan EAPJN 216 dipilih untuk diidentifikasi secara molekuler. Isolasi DNA dilakukan dengan menggunakan Kit isolasi DNA Exgene ${ }^{T M}$ Cell SV, mengikuti protokol isolasi DNA bakteri Gram positif pada GeneAll Exgene ${ }^{T M}$ Protocol Handbook. Hasil isolasi DNA diukur dengan spektrofotometer Nanodrop $2000^{\mathrm{TM}}$ untuk mengetahui konsentrasi DNA yang tepat sebagai template pada analisis PCR. DNA hasil isolasi dielektroforesis di dalam larutan buffer TBE $0,5 \mathrm{x}$ pada mesin elektroforasi berarus listrik $42 \mathrm{~mA}$ dan tegangan 80 volt selama 42 menit. Visualisasi DNA dilakukan menggunakan Geldoc ${ }^{\mathrm{TM}}$.

Amplifikasi DNA dengan PCR standar menggunakan primer universal $16 S \mathrm{rRNA}$

DNA isolat bakteri endofit diamplifikasi dengan primer universal 16S rRNA. Primer yang digunakan adalah Primer forward $8 \mathrm{~F}$ dengan urutan basa 5-AGA GTT TGA TCC TGG CTC AG-3 dan Primer reverse U1492R dengan urutan basa 5-GTT TAC CTT GTT ACG ACTT-3 (Surajit et al., 2014). Campuran reagen PCR menggunakan mix PCR Kappa ${ }^{\mathrm{TM}}$ sebagaimana tercantum pada Tabel 1. Siklus PCR meliputi tahap denaturasi pada suhu $95^{\circ} \mathrm{C}$ selama 3 menit dan 15 detik, tahap annealing pada suhu $46^{\circ} \mathrm{C}$ selama 15 detik, tahap ekstensi pada suhu $72^{\circ} \mathrm{C}$ selama 15 detik dan 7 menit. Total siklus dalam PCR standar ini adalah 35 siklus dengan waktu keseluruhan selama 1 jam 4 menit. Selanjutnya gel agarose $1,5 \%(\mathrm{w} / \mathrm{v})$ dipersiapkan dengan pelarut buffer TBE 0,5x. Elektroforesis dilakukan pada mesin elektroforasi pada arus listrik $40 \mathrm{~mA}$ dengan tegangan 60 volt selama 60 menit. Penanda ukuran DNA (marker) menggunakan $1 \mathrm{~kb}$ ladder. Visualisasi hasil PCR dilakukan menggunakan Geldoc $^{\mathrm{TM}}$.

Empat sampel DNA bakteri endofit potensial hasil amplifikasi dengan PCR diurutkan susunan basa-nya menggunakan 1st Base DNA Sequencing Services Singapura. Urutan basa-basa DNA hasil sequencing kemudian disejajarkan menggunakan program BioEdit Sequence Alignment Editor dan dianalisis lebih lanjut dengan program BLAST-N pada situs www.ncbi.nlm.nih.gov untuk mengetahui spesies isolat bakteri endofit.

\section{Hasil dan Pembahasan}

Isolat cendawan patogen bercak daun

Konidia cendawan Curvularia sp. berukuran 24-40 x 12-22 $\mu \mathrm{m}$ memiliki yang terbagi-bagi, hampir ovoid (bentuk telur) atau hampir elips dengan sel kedua dari dasar berukuran paling besar (Kittimorakul et al., 2013) (Gambar 1). Gejala penyakit yang disebabkan oleh cendawan Curvularia sp. diawali dengan munculnya bercak kecil kekuningan yang perlahan berubah kecoklatan dan lama kelamaan menjadi coklat kehitaman yang menyerang seluruh bagian daun (Kittimorakul et al., 2013).

\section{Uji antibiosis bakteri endofit terhadap cendawan penyebab penyakit bercak daun}

Daya penghambatan bakteri endofit terhadap cendawan Curvularia sp. ditunjukkan oleh 33 isolat bakteri endofit (75\%) dari 40 isolat yang diuji. Lima isolat dengan daya penghambatan terbesar adalah isolat EAKSS 502, EAKSS 520, EAKSS 507, EAKSS 508, dan EAKSS 529.

Tabel 1. Jenis pereaksi yang digunakan dalam PCR standar Table 1. Reagens that used in standard PCR

\begin{tabular}{lcc}
\hline Jenis pereaksi & \multicolumn{2}{c}{ Volume Reaksi PCR } \\
Kind of reagen & \multicolumn{2}{c}{ PCR reaction volume } \\
& $1 \mathrm{x}(\mu \mathrm{L})$ & $6 \mathrm{x}(\mu \mathrm{L})$ \\
\hline Mix PCR Kappa & 12,5 & 75 \\
Primer Forward 16S rRNA 8F (5-AGA GTT TGA TCC TGG CTC AG-3) & 1,25 & 7 \\
Primer Reverse 16S rRNA U1492R (5-GTT TAC CTT GTT ACG ACTT-3) & 1,25 & 7 \\
DNA & 0,5 & 3 \\
Air bebas nuklease/ free nuclease water & 9 & 54 \\
\hline Total & 24,5 & \\
\hline
\end{tabular}



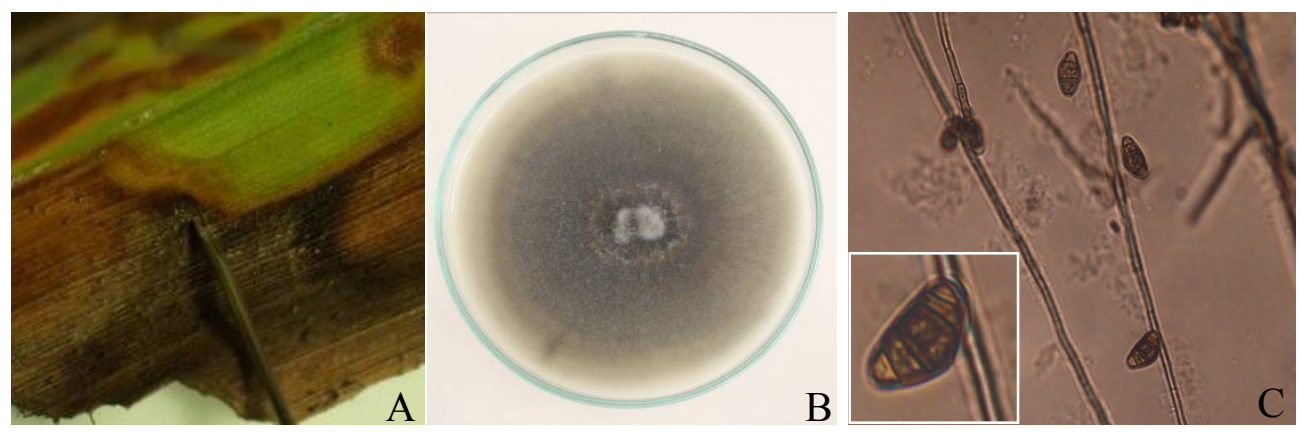

Gambar 1 Gejala penyakit bercak daun Curvularia (A); Kultur murni cendawan Curvularia sp. (B); konidia cendawan Curvularia sp. (C)

Figure 1 Curvularia leaf spot symtomp (A); Isolate of Culvularia sp. (B): Conidia of Culvularia sp. (C)

Sementara itu daya penghambatan pertumbuhan cendawan Curvularia sp. terkecil teramati pada isolat EAAPN 225, EDPJ 006, EAONN 545, EAKPS 503,EAKSS 515 dan EAKSS 522. Tujuh isolat bakteri endofit tidak menunjukkan kemampuan menghambat pertumbuhan cendawan Curvularia sp. yaitu EAKSS 514, EDKS 006, EAKPS 501, EAAPN 237, EAAPN 238, EAAPN 508 dan EDAPN 202 (Tabel 2). Bakteri endofit memiliki kemampuan menghasilkan metabolit atau senyawa kimia tertentu yang menghambat pertumbuhan cendawan patogen bercak daun (Akbaba \& Ozaktan, 2018). Senyawa tersebut bergerak melalui pori-pori media agar hingga mempengaruhi pertumbuhan koloni cendawan. Berdasarkan pengamatan, mekanisme penghambatan bakteri endofit Arecaceae terhadap perkembangan cendawan Curvularia sp. adalah antibiosis dan lisis (Gambar 2).

Pengamatan mikroskopis terhadap pertumbuhan miselium cendawan Curvularia sp. menunjukkan terjadinya respons perubahan warna hifa (menjadi berwarna oranye) secara lokal pada tepi koloni Curvularia sp. disertai dengan penghambatan pertumbuhan koloni cendawan Curvularia sp. Respons berikutnya berupa penghambatan pertumbuhan koloni patogen tanpa perubahan warna koloni. Respons lain yang diperoleh pada pengamatan yakni terjadinya perubahan morfologi koloni ditunjukkan dengan hifa bagian tepi menjadi menebal dan menghitam yang disertai dengan penghambatan pertumbuhan koloni patogen (Gambar 2). Perubahan bentuk hifa (malformasi) cendawan patogen Curvularia sp. yang diakibatkan oleh bakteri endofit mendukung hasil yang dilaporkan Compant et al. (2013) yang menunjukkan kemampuan bakteri endofit Streptomyces alni pada anggur dalam menghasilkan aktivitas penghambatan pertumbuhan, malformasi dan lisis hifa pada pengujian secara in vitro.

Daya penghambatan pertumbuhan dan perubahan warna miselium Curvularia sp. merupakan hasil interaksi senyawa kimia yang diproduksi bakteri endofit terhadap cendawan Curvularia sp. Shalini dan Srivastava (2008) melaporkan bahwa Pseudomonas fluorescens strains (PSB-1, PUR-46, R1, R2 and R3) menghasilkan senyawa kimia asam phenazine-1carboxylic yang secara signifikan mampu menghambat perkembangan koloni cendawan Curvularia lunata hingga $96,07 \%$ bila diujikan pada dosis $5000 \mu \mathrm{g} / \mathrm{mL}$. Sementara itu, cendawan Curvularia sp. dapat menghasilkan metabolit berupa curvularin (curvulone A, hydroxycurvularin, dan dehydroxycurvularin) yang mampu memberikan pengaruh anti bakteri (Zhang et al,. 2011). Dengan demikian daya penghambatan yang tinggi oleh bakteri endofit terhadap cendawan Curvularia sp. diduga disebabkan sifat antibiotik senyawa sekunder yang dihasilkan bakteri endofit lebih kuat dibandingkan dengan metabolit sekunder yang dihasilkan cendawan Curvularia sp.

Pengaruh VOC terhadap perkembangan cendawan Curvularia sp.

Pengujian VOC bakteri endofit terhadap cendawan Curvularia sp. menunjukkan sebanyak 7 isolat bakteri endofit (EAPJN 216, EAKSS 532, EAAPN 225, EAAPN 506, EAAPN 507 dan EAAPN 557) menghasilkan senyawa organik volatil dan mampu menghambat pertumbuhan Curvularia sp. (Gambar 3). Isolat isolat tersebut mampu mennyebabkan pertumbuhan Curvularia sp. berkisar antara 2,79\% - 7,72\% dibandingkan dengan kontrol yang mencapai $100 \%$. Hal ini membuktikan bahwa isolat-isolat bakteri endofit tersebut mampu menghasilkan senyawa menguap (bersifat volatil) yang berpengaruh terhadap perkembangan Curvularia sp. penyebab bercak daun kelabu pada kelapa kopyor secara in vitro. Senyawa organik volatil tersebut salah satunya adalah senyawa fenolat yang dapat menyebabkan rusaknya membran plasma cendawan patogen (Liswarni \& Nurbailis, 2018). 
Tabel 2. Persentase penghambatan bakteri endofit asal Arecaceae terhadap cendawan Curvularia sp. patogen penyebab penyakit bercak daun

Table 2. Result of antibiosys test of endophytic Arecaeae bacteria to Curvularia sp. pathogen that cause fungal leaf spot disease

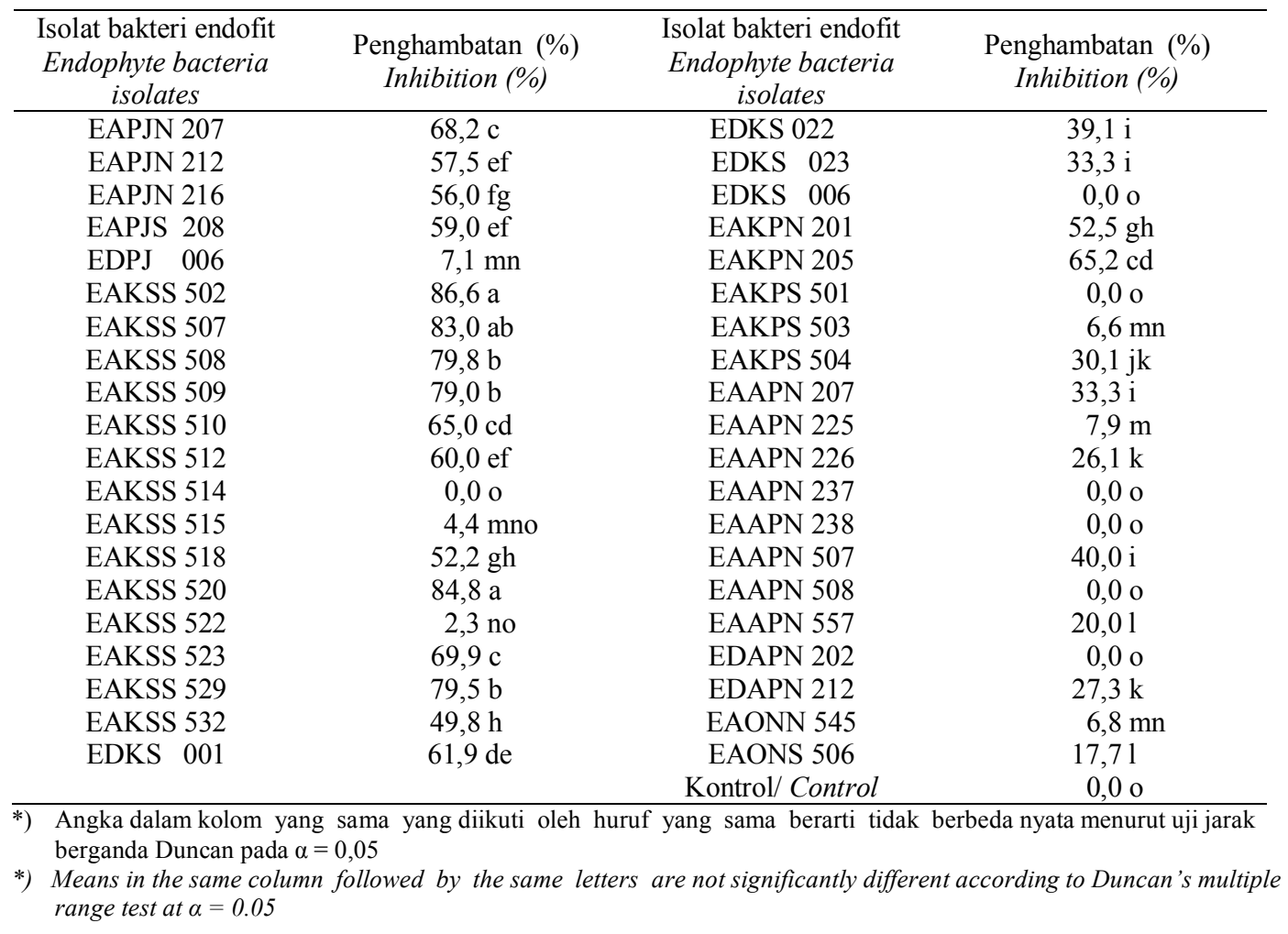

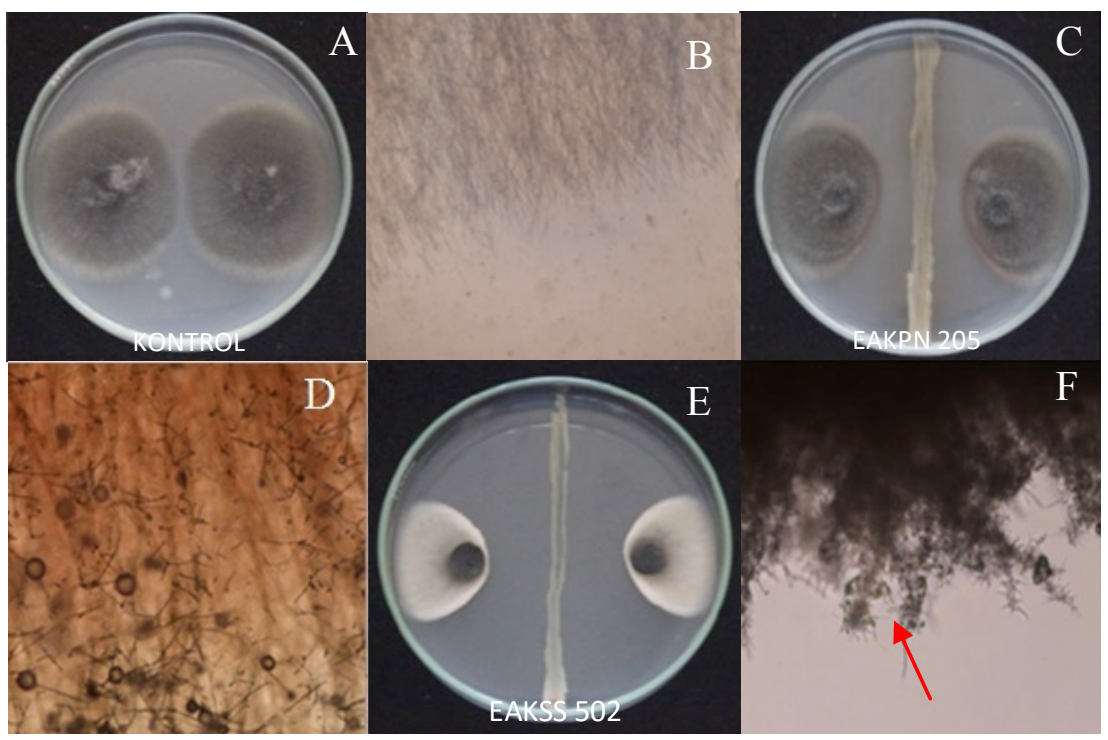

Gambar 2 Uji antibiosis bakteri endofit terhadap cendawan Curvularia sp. Perlakuan kontrol tidak terbentuk zona hambat (A); Hifa cendawan Curvularia sp. normal pada kontrol (B); Uji antibiosis bakteri endofit EAKPN 205 terhadap cendawan Curvularia sp., terbentuk zona hambat dan perubahan warna hifa (C); Hifa cendawan Curvularia sp. mengalami perubahan warna (D); Uji antibiosis bakteri endofit EAKSS 502 terhadap cendawan Curvularia sp., terbentuk zona hambat dan malformasi (E); Hifa cendawan Curvularia sp. mengalami malformasi (F).

Figure 2. Antibiotic test of Arecaceae endophytic bacteria to Curvularia sp. Control treatment has not produced inhibition zone (A); Normal Curvularia sp. mycellium on control (B); Inhibition zone formation and discoloration between EAKPN 205 isolate and Curvularia sp.(C); Discoloration of Curvularia sp. mycellium as an antibiotic effect from endophyte isolate (D); Inhibition zone and malformation formation of Curvularia sp. against EAKSS 502 (E); Malformation of Curvularia sp. mycellium as a respons to antibiotic of endophyte isolate $(F)$. 


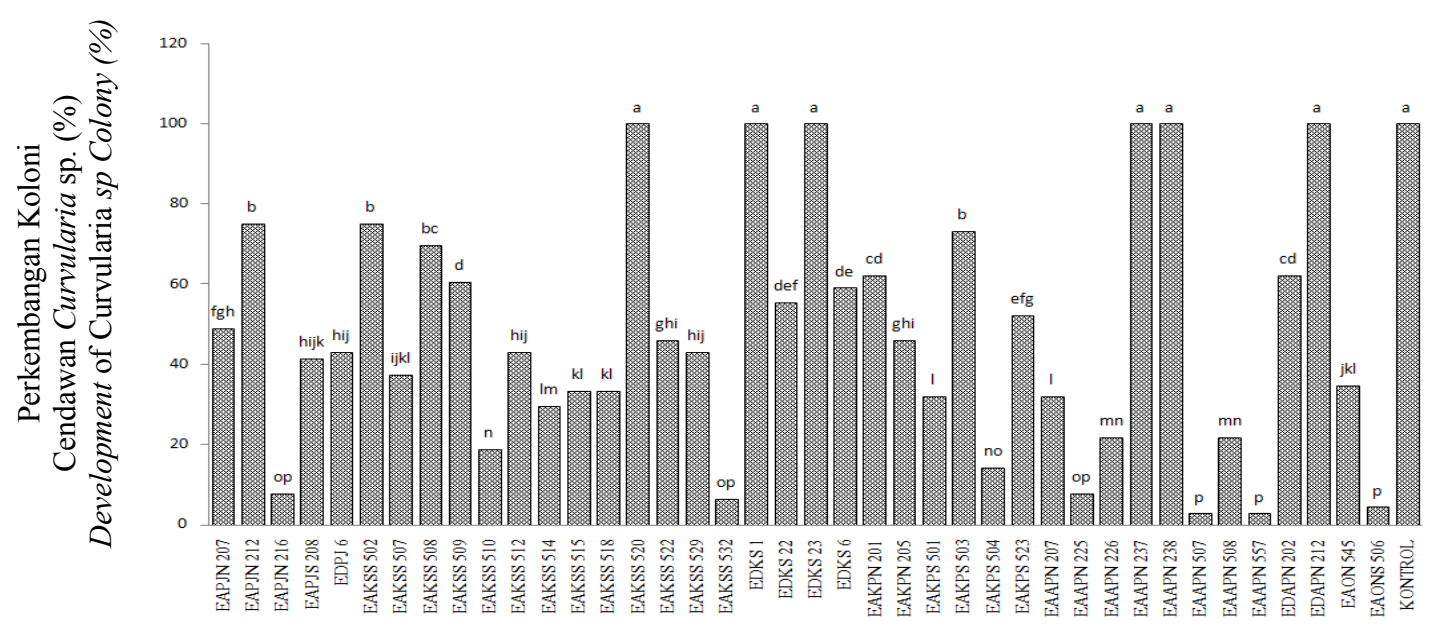

Isolat bakteri endofit/

Endophytic bateria isolates

Gambar 3. Pengaruh senyawa organik volatil (VOC) yang dihasilkan bakteri endofit terhadap perkembangan cendawan Curvularia sp.

Figure 3. The effect of volatile organic compounds (VOCs) produced by endophytic bacteria on the growth of Curvularia sp.

Enam isolat bakteri endofit lain yang diujikan tidak memiliki daya hambat terhadap pertumbuhan cendawan Curvularia sp. Pada perlakuan isolat bakteri endofit tersebut, pertumbuhan koloni Curvularia sp. tidak berbeda nyata dengan kontrol. Isolat bakteri endofit tersebut adalah isolat EAKSS 520, EDKS 1, EDKS 23, EAAPN 237, EAAPN 238 dan EDAPN 212 (Gambar 3). Hal ini menunjukkan bahwa isolat-isolat bakteri endofit tersebut tidak memproduksi senyawa organik volatil sehingga pertumbuhan hifa cendawan Curvularia berkembang secara normal. Bakteri endofit tersebut diduga memiliki peranan terhadap perkembangan tanaman diluar kemampuan untuk menghambat patogen (Ilmiyah et al., 2015).

\section{Identifikasi bakteri endofit dengan primer universal $16 \mathrm{~S}$ rRNA}

Identifikasi secara molekuler dilakukan untuk mengetahui identitas ke-4 isolat bakteri endofit potensial yang dipilih berdasarkan kombinasi data pengujian antibioisis dan produksi senyawa organik volatil. Terdapat 3 isolat bakteri endofit yang berpotensi menghambat perkembangan Curvularia sp. berdasarkan uji antagonis yaitu isolat EAKSS 502, EAKSS 507, EAKPN 201 dan satu isolat bakteri endofit potensial berdasarkan uji VOC yaitu EAPJN 216. Empat genom DNA isolat bakteri endofit potensial diisolasi menggunakan Kit isolasi DNA ExgeneTM Cell SV menghasilkan kualitas DNA \pm 1,9 pada rasio A260/A280. Selanjutnya genom DNA diidentifikasi berdasarkan penanda gen 16S rRNA, yakni bagian DNA yang sangat terjaga (conserved) dalam sel yang menyandikan sejumlah protein subunit kecil ribosom (small subunit ribosom) (Stiegler et al., 1981). Hasil amplifikasi DNA ke empat isolat yang diuji yakni berupa amplikon berukuran $\pm 1500 \mathrm{bp}$, hal ini sesuai dengan Surajit et al., (2014). Hasil visualisasi berupa pita DNA disajikan pada Gambar 4.

Hasil identifikasi molekuler empat isolat bakteri endofit dengan kemampuan antibiosis dan produksi senyawa organik volatil kuat secara berturut-turut dapat dilihat pada Tabel 3. Keempat isolat tersebut merupakan hasil isolasi dari tanaman yang berbeda yakni tanaman kelapa sawit (Elaeis guineensis), kelapa kopyor (Cocos nucifera) dan pejibaye (Bactris gasipaes).

Bakteri Serratia marcescens diketahui mampu memproduksi IAA, senyawa kimia anti patogen dan enzim pendegradasi kitin. Selvakumar et al., (2008) melaporkan S. marcescens mampu memproduksi enzim pendegradasi kitin yang berperan dalam menghambat perkembangan patogen. Vaaje-Kolstad et al., (2013) melaporkan bahwa $S$. marcescens memiliki empat enzim pendegradasi kitin aktif yaitu $\mathrm{ChiC}$, Chia dan Chib serta CBP21. Pada penelitian ini diketahui bahwa tanaman aren (Arenga pinnata) menjadi inang bakteri $S$. marcescens.

Genus Serratia berbentuk batang, masuk dalam bakteri Gram negatif, membentuk endospora, bersifat anaerob fakultatif termasuk ke dalam famili Enterobacteriaceae (Li et al., 2015). Bakteri genus ini hidup dan berkembang pada beragam habitat diantaranya tanah (Lavania \& Nautiyal 2013), sebagai endofit tanaman (Lim et al., 2015;. 
Afzal et al., 2016; Zaheer et al., 2016), hidup di gua kelelawar (García-Fraile et al., 2015), hidup dalam jaringan tubuh nematoda (Abebe-Akele et al., 2015; Vicente et al., 2016), dan manusia (Bonnin et al., 2015). Serratia mampu meningkatkan pertumbuhan tanaman melalui produksi senyawa siderophores, lipokitin, oligosakarida oleh karena itu dikelompokkan sebagai rhizobakteria perangsang pertumbuhan tanaman (Purushotham et al., 2012). Genus ini diketahui pula mampu menghasilkan sejumlah senyawa kimia yang mampu menghambat perkembangan mikroorganisme lain seperti prodiginine (prodigiosin, undecylprodigiosin, cycloprodigiosin, cyclononylprodigiosin, butilmeta-cyclo-heptylprodiginine) yang diproduksi dan disekresikan oleh Serratia dan menjadi anti mikroba penciri khas genus tersebut (Williamson et al., 2006).

Isolat EAKSS 507 diidentifikasi sebagai bakteri Burkholderia sp. berdasarkan analisis program Blast. Isolat EAKSS 507 memiliki tingkat penghambatan berupa antibiosis yang cukup tinggi terhadap 3 cendawan bercak yang diujikan secara in vitro. Jiang et al. (2008) melaporkan bahwa bakteri endofit Burkholderia mampu melarutkan fosfat, memproduksi ACC deaminase, IAA, siderofor, dan melarutkan logam berat. Saxena (2010) melaporkan terdapat strain bakteri Bulkhorderia yang mampu menghasilkan enzim pendegradasi kitin. Shimosaka et al.,(2001) juga melaporkan terdapat 2 gen pengkode kitinase yang diperoleh dari Burkholderia spp yakni kitinase A dan B (ChiA and ChiB). Li et al., (2011) melaporkan bahwa rhizobacterium Burkholderia mampu mengurangi kejadian dan keparahan penyakit hawar pelepah pada padi pada kondisi rumah kaca. Isolat EAKSS 507 diidentifikasi sebagai Burkholderia sp. strain DOP Ma316 yang diperoleh dari akar tanaman kelapa sawit, hal ini mendukung Sapak et al. (2008) yang menyatakan terdapat bakteri endofit Burkholderia dari akar tanaman kelapa sawit, yang mampu menurukan insidensi penyakit, salah satunya busuk pangkal batang hingga $42 \%$ pada 8 bulan setelah inokulasi.

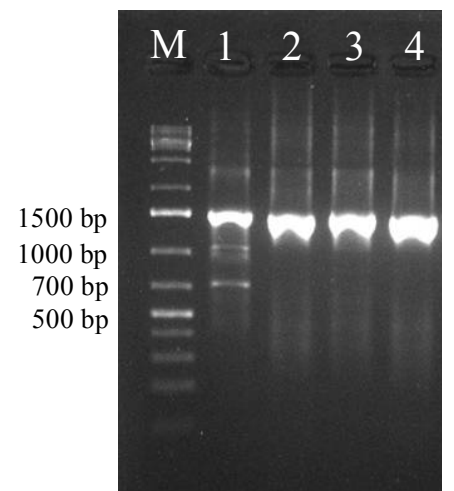

Gambar 4 Elektroforegram hasil PCR isolat bakteri endofit Arecaceae potensial menggunakan Primer 16S rRNA, secara berurutan dari kiri ke kanan: $1 \mathrm{~kb}$ ladder (M), isolat bakteri endofit EAKSS 502 (1), EAKSS 507 (2), EAPJN 216 (3) dan EAKPN 201(4)

Figure 4 Electroforegram of potential endophytic Arecaceae bacteria isolates PCR product amplified using $16 \mathrm{~S}$ rRNA Primer, sequentially from left to right: $1 \mathrm{~kb}$ ladder (M), endophytic bacterial isolates EAKSS 502 (1), EAKSS 507 (2), EAPJN 216 (3) and EAKPN 201 (4)

Tabel 3. Hasil identifikasi 4 isolat bakteri endofit potensial secara molekuler

Table 3. Molecular identification of 4 isolates of potential endophytic bacteria

\begin{tabular}{|c|c|c|c|c|c|}
\hline $\begin{array}{l}\text { Isolat } \\
\text { Isolates }\end{array}$ & $\begin{array}{l}\text { Dasar pemilihan } \\
\text { Choice Reason }\end{array}$ & $\begin{array}{l}\text { Identitas } \\
\text { Identity }\end{array}$ & $\begin{array}{l}\text { Kode aksesi } \\
\text { Acsesion code }\end{array}$ & $\begin{array}{c}\text { Identitas } \\
\text { matriks }(\%) \\
\text { Identity } \\
\text { matrix }(\%) \\
\end{array}$ & $\begin{array}{l}\text { Query } \\
\text { cover } \\
(\%)\end{array}$ \\
\hline EAKSS 502 & $\begin{array}{l}\text { Antibiosis kuat/ } \\
\text { strong antibiotic } \\
\text { respons }\end{array}$ & Serratia marcescens strain PIGB81 & KU364021.1 & 94 & 98 \\
\hline EAKSS 507 & $\begin{array}{l}\text { Antibiosis Kuat/ } \\
\text { strong antibiotic } \\
\text { respons }\end{array}$ & Burkholdera sp. DOP Ma316 & KT993571.1 & 94 & 99 \\
\hline EAKPN 201 & $\begin{array}{l}\text { Antibiosis kuat/ } \\
\text { strong antibiotic } \\
\text { respons }\end{array}$ & Serratia marcescens strain RY21 & KC790294.1 & 94 & 98 \\
\hline EAPJN 216 & $\begin{array}{l}\text { VOC kuat/strong } \\
\text { VOC }\end{array}$ & Serratia marcescens strain LB21 & KC335216.1 & 94 & 99 \\
\hline
\end{tabular}




\section{Kesimpulan}

Sebanyak 33 isolat bakteri endofit dari 40 isolat terseleksi menunjukkan daya penghambatan terhadap cendawan Curvularia sp. yang diisolasi dari kelapa kopyor pada uji antibiosis dengan kisaran penghambatan 4,4\% - 86,6\%. Lima isolat dengan nilai penghambatan terbesar berdasarkan uji antibiosis adalah EAKSS 502, EAKSS 520, EAKSS 507, EAKSS 508 dan EAKSS 529. Pada pengujian produksi senyawa organik volatil, isolat EAPJN 216, EAKSS 532, EAAPN 225, EAAPN 506, EAAPN 507 dan EAAPN 557 menghasilkan senyawa organik volatil yang menekan pertumbuhan koloni cendawan Curvularia sp. pada kisaran 92,27\% - 97,21\%. Berdasarkan kombinasi data pengujian antibioisis dan produksi senyawa organik volatil terpilih 4 isolat bakteri endofit yang berpotensi menghambat perkembangan Curvularia sp. yaitu isolat EAKSS 502, EAKSS 507, EAKPN 201 dan EAPJN 216. Isolat-isolat tersebut berhasil diidentifikasi secara berturut-turut sebagai bakteri Serratia marcescens strain PIGB81, Burkholderia sp. DOP Ma316, S. marcescens strain $R Y 21$ dan $S$. marcescens strain LB21.

\section{Daftar Pustaka}

Abebe-Akele F, LS Tisa, VS Cooper, PJ Hatcher \& E Abebe, WK Thomas (2015). Genome sequence and comparative analysis of a putative entomopathogenic Serratia isolated from Caenorhabditis briggsae. BMC genomics 16(1), 531.

Adeline SYT, M Sariah, K Jugah, R Son \& S Gurmit (2008). Endophytic microorganisms as potential growth promoters of banana. Biocontrol 53, 541-553.

Afzal I, I Iqrar, ZK Shinwari \& A Yasmin (2016). Plant growth-promoting potential of endophytic bacteria isolated from roots of wild Dodonaea viscosa L. Plant Growth Regulation 12(1), 1-10.

Akbaba, M., \& Ozaktan, H. (2018). Biocontrol of angular leaf spot disease and colonization of cucumber (Cucumis sativus L.) by endophytic bacteria. Egyptian Journal of Biological Pest Control 28(1), 14.

Bonnin RA, D Girlich, D Imanci, L Dortet \& T Naas (2015). Draft genome sequence of the Serratia rubidaea CIP 103234T reference strain, a human-opportunistic pathogen. Genome announcements 3(6), 1340-1345.

Compant S, Brader G, Muzammil S, Sessitsch A, Lebrihi A, \& Mathieu F (2013). Use of beneficial bacteria and their secondary metabolites to control grapevine pathogen diseases. BioControl 58(4), 435-455.

Eris DD, A Munif, BPW Soekarno \& A Purwantara (2017). Penapisan dan potensi bakteri endofit asal tanaman Arecaceae sebagai agens pengendali hayati cendawan Pestalotiopsis sp. penyebab penyakit bercak daun pada kelapa kopyor (Cocos nucifera). Menara Perkebunan 85 (1), 19-27.

García-Fraile P, M Chudickova, O Benada, J Pikula M \& Kolarik (2015). Serratia myotis sp. nov. and Serratia vespertilionis sp. nov., isolated from bats hibernating in caves. International journal of systematic and evolutionary microbiology 65(1), 90-94.

Hallmann J, A Quadt-Hallmann, WG Miller, RA Sikora \& SE Lindow (2001). Endophyte colonization of plants by biocontrol agent Rhizobium etli G12 in relation to Meloidogyne incognita infection. Phytophatol 91, 415-422.

Harni R \& A Munif (2012). Pemanfaatan agens hayati endofit untuk mengendalikan penyakit kuning pada tanaman lada. Jurnal Tanaman Industri dan Penyegar 3, 201-206.

Ilmiyah Z (2015). Uji antagonisme jamur endofit tanaman stroberi terhadap Alternaria alternata jamur penyebab bercak daun (Leaf Spot) pada tanaman stroberi secara in vitro. LenteraBio 4(1), 19-24.

Jiang CY, XF Sheng, M Qian \& QY Wang (2008). Isolation and characterization of a heavy metalresistant Burkholderia sp. from heavy metalcontaminated paddy field soil and its potential in promoting plant growth and heavy metal accumulation in metal-polluted soil. Chemosphere 2, 157-64.

Kittimorakul J, C Pornsuriya, A SunPapao \& V Petcharat (2013). Survey and incidence of leaf blight and leaf spot disease of oil palm seedling in southern Thailand. Plant Pathology Journal 12(3), 149-153.

Lavania M \& CS Nautiyal (2013). Solubilization of Tricalcium phosphate by temperature and salt tolerant Serratia marcescens NBRI1213 isolated from alkaline soils. African Journal of Microbiology Research 7(34), 4403-4413.

Li B, BP Liu, RR Yu, MM Lou, YL Wang, GL Xie, HY Li \& GC Sun (2011). Phenotypic and molecular characterization of rhizobacterium Burkholderia sp. strain R456 antagonistic to Rhizoctonia solani, sheath blight of rice. World Journal of Microbiology and Biotechnology 27(10), 2305-2313. 
Lim YL, DR Yong, T Krishnan, KK Tee, WF Yin \& KG Chan (2015). Complete genome sequence of Serratia fonticola DSM 4576 T, a potential plant growth promoting bacterium. Journal of Biotechnology 214, 43-44.

Liswarni Y \& Nurbailis MB (2018). Eksplorasi cendawan endofit dan potensinya untuk pengendalian Phytophthora palmivora penyebab penyakit busuk buah kakao. PROS SEM NAS MASY BIODIV INDON 4(2), 231235

Munif A \& Giyanto G (2015). Effectiveness of endophytic bacterial consortium of coffee plant on mortality of Pratylenchus coffeae in vitro. Pelita Perkebunan 31(3), 175-185.

Munif A, S Wiyono \& Suwarno (2012). Isolasi bakteri endofit asal padi gogo dan potensinya sebagai agens biokontrol dan pemacu pertumbuhan. Jurnal Fitopatologi Indonesia 8(3), 57-64.

Purushotham P, PPS Arun, JS Prakash \& AR Podile (2012). Chitin binding proteins act synergistically with chitinases in Serratia proteamaculans 568. PLoS One 7(5), 234-242.

Rajendran L, G Karthikeyan, T Raguchander \& R Sumiyappen (2012). Cloning and sequencing of novel endophytic Bacillus subtilis from coconut for the management of basal stem rot disease. Asian Journal of Plant Pathology 2(1), $1-14$.

Sapak Z, S Meon \& Z Ahmad Mior (2008). Effect of endophytic bacteria on growth and suppression of Ganoderma infection in oil palm. International Journal of Agriculture \& Biology 10, 127-32.

Saxena J (2010). Disease suppression and crop improvement in moong beans (Vigna radiata) through Pseudomonas and Burkholderia strains isolated from semi arid region of Rajasthan, India. BioControl 55(6), 799-810.

Selvakumar G, M Mohan, S Kundu, AD Gupta, P Joshi, S Nazim \& HS Gupta (2008). Cold tolerance and plant growth promotion potential of Serratia marcescens strain SRM (MTCC 8708 ) isolated from flowers of summer squash (Cucurbita pepo). Letters in applied microbiology 46(2), 171-175.

Shalini \& R Srivastava (2008). Antifungal activity of Pseudomonas fluorescens against different plant pathogenic fungi. Elec J Env Agricult Food Chem 7, 2789-2796.

Shimosaka M, Y Fukumori, T Narita, XY Zhang, R Kodaira, M Nogawa \& M Okazaki (2001). The bacterium Burkholderia gladioli strain
CHB101 produces two different kinds of chitinases belonging to families 18 and 19 of the glycosyl hydrolases. Journal of bioscience and bioengineering 91(1), 103-105.

Stiegler P, P Carbon, JP Ebel \& C Ehresmann (1981). A General secondary-structure model for procaryotic and eucaryotic RNAs of the small ribosomal subunits. European Journal of Biochemistry 3, 487-95.

Surajit D, R Hirak, Dash, M Neelam, C Jaya \& K Supriya (2014). Understanding molecular identification and polyphasic taxonomic approaches for genetic relatedness and phylogenetic relationships of microorganisms. Journal of Microbiological Methods 103, 80100.

Tanaka M, H Sukiman, M Takebayashi, K Saito, M Suto, MS Prana \& F Tomita (1999). Isolation, screening and phylogenetic identification of endophytes from plants in Hokaido Japan and java Indonesia. Microbes and Environment 14(4), 237-241.

Vaaje-Kolstad G, SJ Horn, M Sorlie \& VG Eijsink (2013). The chitinolytic machinery of Serratia marcescens-a model system for enzymatic degradation of recalcitrant polysaccharides. FEBS Journal 280(13), 3028-3049.

Vicente CS, Nascimento FX, Y Ikuyo, PJ Cock, M Mota \& K Hasegawa (2016). The genome and genetics of a high oxidative stress tolerant Serratia sp. LCN16 isolated from the plant parasitic nematode Bursaphelenchus xylophilus. BMC genomics 17(1), 301.

Williamson NR, PC Fineran, FJ Leeper \& GP Salmond (2006). The biosynthesis and regulation of bacterial prodiginines. Nature Reviews Microbiology 4(12), 887-899.

Yuan J, W Raza, Q Shen \& Q Huang (2012). Antifungal activity of Bacillus amyloliquefaciens NJN-6 volatile compounds against Fusarium oxysporum f. sp. cubense. Applied and Environmental Microbiology 78(16), 5942-594.

Zaheer A, B Mirza, JE Mclean, S Yasmin, TM Shah, KA Malik \& MS Mirza (2016). Association of plant growth-promoting Serratia spp. with the root nodules of chickpea. Research in Microbiology 6(167), 510-520.

Zhang YL, LC Kong, DH Jiang, CP Yin, QM Cai, Q Chen \& JY Zheng (2011). Phytotoxic and antifungal metabolites from Curvularia sp. FH01 isolated from the gut of Atractomorpha sinensis. Bioresource technology 102(3), 35757. 